КРИТЕРІЇ, ПОКАЗНИКИ ТА РІВНІ СФОРМОВАНОСТІ ПРОФЕСІЙНО-ПРАКТИЧНОЇ КОМПЕТЕНТНОСТІ

МАЙБУТНІХ УЧИТЕЛІВ ІНФОРМАТИКИ ЩОДО ВИКОРИСТАННЯ ХМАРО ОРІЕНТОВАНОГО СЕРЕДОВИЩА У НАВЧАННІ БАЗ ДАНИХ

\title{
CRITERIA, CHARACTERISTICS AND LEVELS OF PROFESSIONAL AND PRACTICAL COMPETENCE OF FUTURE TEACHERS OF COMPUTER SCIENCE IN TERMS OF THE USE OF THE CLOUD-ORIENTED ENVIRONMENT IN TEACHING DATABASES
}

\begin{abstract}
у статmі надано визначення професійнопрактичної компетентності майбутнього вчителя інформатики, охарактеризовані ролі майбутнього вчителя інформатики у сучасному закладі загальної середньої освіти (провідний фрахівець в галузі інфрорматики; консультант та помічник для колег у галузі IKT; експерт у використанні IKT для адміністрації школи; учитель), висвітлено місце баз даних при підготовці майбутніх учителів інфрорматики, представлені підходи вітчизняних науковців щодо виокремлення рівнів сорормованості професійних компетент ностей майбутніх учителів. Виокремлено критерії для оцінювання рівня сорормованості профресійно-практичної компетентності майбутніх учителів інформатики щодо використання хмаро орієнтованого середовища у навчанні баз даних: мотиваційний (характеризує наявність мотивації в майбутніх учителів інфрорматики щодо використання хмаро орієнтованого середовища у профеесійній діяльності та навчанні баз даних), організаційний (здатність майбутніх учителів інфрорматики у навчанні баз даних у хмаро орієнтованому середовище), діяльнісний (здатність студентів здійснювати навчальну, самостійну та комунікаційну діяльність у хмаро орієнтованому середовище), когнітивний (визначає рівень знань майбутніх учителів інформатики з баз даних у хмаро орієнтованому середовище), критерій навчальної взаємодії (здатність майбутніх учителів інформатики здійснювати навчальну взаємодію у хмаро орієнтованому середовище, використовуючи хмаро орієнтовані системи дистанчійного навчання та хмаро орієнтованих засобів у навчанні баз даних), їх показники та рівні (низький, середній, достатній, високий). Наведена процедура оцінювання рівня сорормованості професійно-практич ної компетентності майбутніх учителів інфрорматики щодо використання хмаро орієнтованого середовища у навчанні баз даних, а саме: кожний показник профресійнопрактичної компетентності має відповідний ваговий коефічієнт, якому у відповідність ставиться п'ятибальна шкала оцінювання, сумарна оцінка за всіма критеріями визначає на рівень сфрормованості вищезгаданої компетентності майбутнього вчителя інорорматики.
\end{abstract}

Ключові слова: хмаро орієнтоване сере довище, хмаро орієнтовані засоби, хмаро орієнтована система дистанційного навчання, профресійно-практична компетентність, майбутні вчителі інфрорматики.

The article defines the professional practical competence of the future teacher of informatics, describes the role of the future teacher of informatics in the modern institution of general secondary education (a leading specialist in the field of computer science; consultant and assistant for colleagues in the field of information and communication technologies; expert in using information and communication technologies for school administration; teacher), highlights the place of databases in the preparation of future teachers of informatics, the approaches of national scientists to the competencies of formalization. The criteria for assessing the level of professional practical competence of future informatics teachers regarding the use of cloud oriented environment in database training are distinguished: motivational (characterizing the presence of motivation in future teachers of informatics for the use of cloud oriented environment in professional data and learning computer science teachers in learning database in a cloud oriented environment), active (students' ability to teaching, selfcommunication and communication activities in a cloud oriented environment), cognitive (determines the level of knowledge of future computer science teachers from databases in a cloud oriented environment), the criterion of educational interaction (the ability of future computer science teachers to interact with the learning interaction system training and cloud oriented tools in learning databases), their performance and levels (low, medium, sufficient, high). The procedure for estimating the level of professional practical competence of future informatics teachers regarding the use of the cloud oriented environment in the training of databases is presented, namely: each indicator of professional practical competence has a corresponding weighting factor, to which a five-point assessment scale is put, The criteria determines the level of competence of the future computer science teacher mentioned above. Key words: cloud oriented environment, cloud oriented means, cloud oriented system for distance learning, professional practical competence, future teachers of Information.
Постановка проблеми в загальному вигляді. Основу змісту сучасної вищої педагогічної освіти й вимог до фрахової підготовки майбутніх учителів інформатики складає компетентнісний підхід, згідно з яким кінцевими результатами освітнього процесу у закладі вищої освіти (ЗВО) є фрорму- вання профресійних компетентностей майбутнього вчителя закладу загальної середньої освіти (33CO).

Проблема дослідження $€$ наразі актуальною у зв'язку з тим, що в інноваційному розвитку вищої педагогічної освіти відбувається постійне вдоско- 
налення навчального середовища (HC) майбутніх педагогів завдяки впровадженню сучасних IKT та нових методик навчання.

Аналіз останніх досліджень і публікацій. Особливості профресійної підготовки майбутніх учителів інфрорматики досліджували: І.В. Гирка [2], М.І. Жалдак [3], Н.В. Морзе [6], О.М. Спірін [10] та ін.

Зокрема, О.М. Спірін [10] приділяє увагу питанню теоретичних і методичних засад професійної підготовки майбутніх учителів інформатики за кредитно-модульною системою. Автор визначає основною метою останньої $€$ формування знань, умінь і навичок майбутньої професійної діяльності як основи професійної компетентності вчителя інформатики.

І.В. Гирка [2], у свою чергу, розглядає процес фахової підготовки майбутніх учителів інформатики та виокремлює організаційно-педагогічні умови фрормування їх професійної компетентності.

M.І. Жалдак [3] обґрунтував структуру профресійної підготовки майбутніх учителів інфрорматики до педагогічної діяльності у 3ВО, яка містить багато компонентів і заснована на концепції фрормування інформаційної культури вчителя та спеціальній і методичній його підготовці.

Виділення не вирішених раніше частин загальної проблеми. Сучасне НС для підготовки майбутніх учителів інформатики повинно відповідати вимогам інформаційного суспільства, нинішньому стану розвитку IКТ, стандартам вищої освіти України, його можна створити за допомогою використання хмарних обчислень, що широко починають упроваджувати у навчальні дисципліни у ЗВО 3 метою організації співпраці суб'єктів навчання, комунікації, зберігання великих обсягів навчального матеріалу, планування навчальних подій тощо. Професійна діяльність майбутніх вчителів інфрорматики тісно пов'язана з такими IKT, тому вони повинні вміти застосовувати їх в освітньому процесі, а також займатися самоосвітою в цьому напрямі.

У низці наукових праць закордонних і вітчизняних авторів висвітлено теоретичні та практичні основи застосування хмарних обчислень в освіті, однак проблема сорормованості професійнопрактичної компетентності майбутніх учителів інорорматики щодо використання хмарних обчислень для організації ефективного навчального середовища майбутніх учителів інорорматики при вивченні окремих дисциплін, зокрема баз даних, $€$ порівняно новою та малодослідженою.

Мета статті - визначити критерії, показники та рівні сорормованості професійно-практичної компетентності майбутніх учителів інформатики щодо використання хмаро орієнтованого середовища у навчанні баз даних.

Виклад основного матеріалу. Візьмемо за основу загальну структуру й орієнтовну класифрікацію компетентностей майбутнього вчителя інсрорматики, запропоновану О.М. Спіріним [10]. Із підгрупи професійно-спеціалізованих компетентностей виокремимо професійно-практичну, що, за визначенням автора, є компетентністю, якою має володіти випускник із позицій роботодавця. Таким роботодавцем може бути директор 33СО, директор закладу профресійної освіти, ректор ЗВО, ректор закладу післядипломної педагогічної освіти, директор позашкільного закладу освіти, начальник управління освіти, який, приймаючи на роботу випускника 3ВО за професійною кваліфікацією «Вчитель інформатики» зацікавлений насамперед у його вміннях використовувати сучасні IKT в освітньому процесі та його професійних навичках у галузі інсрорматики.

Під професійно-практичною компетентністю майбутнього вчителя інфрорматики щодо використання хмаро орієнтованого середовища у навчанні баз даних розуміємо підтверджену здатність майбутнього вчителя інформатики реалізовувати профресійну діяльність у галузі баз даних на основі набутих теоретичних знань, практичних вмінь й навичок, ставлень, особистісних якостей і досвіду, якими він оволодів під час навчання баз даних у хмаро орієнтованому середовище (ХOC).

3 погляду сучасного 33СО, майбутній вчитель інфрорматики як випускник педагогічного ЗВО, виступає в декількох взаємопов'язаних ролях: перша - роль провідного фрахівця в галузі інфрорматики та IKT; друга - роль консультанта та помічника для колег у галузі IKT; mретя - роль експерта у використанні IKT в управлінні навчальним закладом для адміністрації школи; четверта - роль учителя для учнів. Він допомагає в процесах автоматизації документообігу школи, внесення даних до ЄДБО, закупівлі та підтримки робочого стану комп'ютерної техніки в школі тощо. Наразі обсяги повідомлень, що накопичуються у школі, з кожним днем зростають, тому назріло питання створення електронних інфрормаційних баз даних (БД), де б зберігалися дані про учителів, учнів, їх батьків, розклад, книжковий фонд школи, обладнання й техніку, медичний кабінет тощо. До переваг таких БД належить: зберігання великих обсягів шкільних даних, які зараз зберігаються переважно в паперовому вигляді; швидкість знаходження потрібних даних; швидкість фрормування звітної документації; подання даних у доступній для розуміння формі; розмежування прав доступу користувачів до даних тощо. Такі БД характеризуються надійністю зберігання даних, їх захистом, достовірністю, оперативністю надання, актуальністю, повнотою, точністю. Тому процес фрормування ППК майбутніх учителів інорорматики щодо використання ХOC у навчанні баз даних є доцільним та актуальним.

Для оцінювання сорормованості ППК майбутнього вчителя інформатики щодо використання ХОС у навчанні БД потрібно: 
- визначити основні критерії та для кожного 3 них встановити певні показники сформованості ППК, за якими можна з'ясувати, чи оволодів майбутній учитель інфрорматики теоретичними знаннями, практичними вміннями й навичками з БД на відповідному рівні та чи здатний він здійснювати подальшу професійну діяльність у ХOC;

- вказати рівні сорормованості ППК майбутніх учителів інформатики щодо використання ХОС у навчанні БД;

- визначити процедуру оцінювання рівня сорормованості ППК майбутнього вчителя інформатики щодо використання ХОС у навчанні БД.

Скористаємося основними положеннями критеріального підходу як методу дослідження, суть якого - виокремлення критеріїв і показників ППК майбутніх учителів інорорматики щодо використання ХОС у навчанні БД для оцінювання рівнів сорормованості зазначеної компетентності. Визначаємо такі критерії ППК студентів:

- мотиваційний (мотивація до використання ХОС, навчання БД та самонавчання) - характеризує наявність мотивації в майбутніх учителів інформатики щодо використання ХОС у профресійній діяльності та навчанні баз даних;

- організаційний (здатність працювати 3 глобальною мережею Інтернет, встановлювати й налаштовувати ПЗ, демонструвати вміння 3 використання хмарних сервісів, здатність використовувати хмаро орієнтовані засоби (ХО3) у навчанні БД, здатність використовувати хмаро орієнтовані системи дистанційного навчання (ХОСДН) у навчанні БД) - визначає здатність майбутніх учителів інорорматики у навчанні БД у ХOC;
- діяльнісний (здатність студентів здійснювати навчальну, самостійну та комунікаційну діяльність у ХОС) - відповідає здатності майбутніх учителів інформатики провадити різноманітну діяльність y XOC;

- когнітивний (здатність демонструвати вміння використовувати мову запитів SQL у XO3 у навчанні БД; здатність демонструвати базові знання з теорії БД; здатність демонструвати уміння з проектування структури реляційної БД; здатність демонструвати розуміння базових компонентів середовища, фрункціоналу СКБД) - визначає рівень знань майбутніх учителів інфрорматики з баз даних у ХOC;

- навчальної взаємодії (здатність демонструвати навчальний матеріал засобами відеоконфреренції, використовувати засоби комунікації, співпраці, зберігання електронних навчальних матеріалів, планування в ХОС) - виявляє здатність майбутніх учителів інформатики здійснювати навчальну взаємодію в ХОС, використовуючи ХОСДН та ХОЗ у навчанні БД.

Для виокремлених критеріїв оцінювання рівня сорормованості ППК майбутнього вчителя інфрорматики щодо використання ХOC у навчанні БД визначили низку відповідних показників, представлених у табл. 1. Також у таблиці зазначено, якими ваговими коефіцієнтами позначені критерії та їхні показники.

Усі подані вище критерії утворюють вектор критеріїв ППК окремого майбутнього вчителя інфрорматики у XOC - k ( $\left.\mathrm{k}_{1}, \mathrm{k}_{2}, \mathrm{k}_{3}, \mathrm{k}_{4}, \mathrm{k}_{5}\right)$. Запропонуємо для оцінки кожного показника таку 5-тибальну школу: 0 - показник не дотримується, 1 - низький рівень дотриманості показника, 2 - середній рівень

Таблиця 1

Критерії та показники оцінювання рівня сформованості ППК майбутніх учителів інформатики щодо використання ХОС у навчанні БД

\begin{tabular}{|c|c|}
\hline Критерій & Показники \\
\hline $\begin{array}{l}\text { Мотиваційний } \\
\text { критерій } \\
\text { (ваговий коефрі- } \\
\text { цієнт }-\mathbf{k}_{\mathbf{1}} \text { ) }\end{array}$ & $\begin{array}{l}\left.\text { 1) мотивація до використання ХОС (ваговий коефіцієнт }-k_{1.1}\right) \text {; } \\
\text { 2) мотивація до навчання БД }\left(k_{1.2}\right) \text {; } \\
\text { 3) мотивація до самонавчання }\left(k_{1.3}\right) \text {. }\end{array}$ \\
\hline $\begin{array}{l}\text { Організаційний } \\
\text { критерій } \\
\left(\mathbf{k}_{\mathbf{2}}\right)\end{array}$ & $\begin{array}{l}\text { 1) здатність працювати з глобальною мережею Інтернет }\left(k_{2.1}\right) \text {; } \\
\text { 2) здатність встановлювати й налаштовувати програмного забезпечення }(П 3), \text { зокрема систем } \\
\text { керування базами даних (СКБД) }\left(k_{2.2}\right) \text {; } \\
\text { 3) здатність демонструвати вміння } 3 \text { використання хмарних сервісів }\left(k_{2.3}\right) ; \\
\text { 4) здатність використовувати ХОЗ у навчанні БД }\left(k_{2.4}\right) ; \\
\text { 5) здатність використовувати ХОСДН у навчанні БД }\left(k_{2.5}\right) .\end{array}$ \\
\hline $\begin{array}{l}\text { Діяльнісний } \\
\text { критерій } \\
\left(\mathbf{k}_{\mathbf{3}}\right)\end{array}$ & $\begin{array}{l}\text { 1) здатність майбутніх учителів інфрорматики здійснювати навчальну діяльність у ХOC }\left(k_{3.1}\right) ; \\
\text { 2) здатність майбутніх учителів інформатики здійснювати самостійну діяльність у ХOC }\left(k_{3.2}\right) \text {; } \\
\text { 3) здатність майбутніх учителів інфрорматики здійснювати комунікаційну діяльність у XOC }\left(k_{3.3}\right) \text {. }\end{array}$ \\
\hline $\begin{array}{l}\text { Когнітивний } \\
\text { критерій } \\
\left(\mathbf{k}_{\mathbf{4}}\right)\end{array}$ & $\begin{array}{l}\text { 1) здатність демонструвати вміння використовувати мову запитів SQL у XO3 у навчанні БД }\left(k_{4.1}\right) \text {; } \\
\text { 2) здатність демонструвати базові знання з теорії БД }\left(k_{4.2}\right) \text {; } \\
\text { 3) здатність демонструвати уміння з проектування структури реляційної БД }\left(k_{4.3}\right) \text {; } \\
\text { 4) здатність демонструвати розуміння базових компонентів середовища, функціоналу СКБД }\left(k_{4.4}\right) \text {. }\end{array}$ \\
\hline $\begin{array}{l}\text { Критерій } \\
\text { навчальної } \\
\text { взаємодії } \\
\left(\mathbf{k}_{5}\right)\end{array}$ & $\begin{array}{l}\text { 1) здатність демонструвати навчальний матеріал засобами відеоконоеренції в ХOC }\left(k_{5.1}\right) \text {; } \\
\text { 2) здатність використовувати засоби комунікації в навчанні БД у ХOC }\left(k_{5.2}\right) ; \\
\text { 3) здатність використовувати засоби співпраці в навчанні БД у ХOC }\left(k_{5.3}\right) \text {; } \\
\text { 4) здатність використовувати засоби зберігання електронних навчальних матеріалів у ХOC }\left(k_{5.4}\right) \text {; } \\
\text { 5) здатність використовувати засоби планування в навчанні БД у ХOC }\left(k_{5.5}\right) \text {. }\end{array}$ \\
\hline
\end{tabular}




\section{Рівні та показники сформованості ППК майбутнього вчителя інфрорматики щодо використання ХОС у навчанні БД}

\begin{tabular}{|c|l|}
\hline $\begin{array}{c}\text { Pівень сорормованості } \\
\text { (назва, бали) }\end{array}$ & \multicolumn{1}{|c|}{ Показники сорормованості } \\
\hline $\begin{array}{c}\text { Низький } \\
(0-20)\end{array}$ & $\begin{array}{l}\text { Володіє необхідними прийомами роботи в ХОС. За допомогою викладача відтворює } \\
\text { отримані знання; наводить приклади з лекцій, практичних занять тощо; неповно } \\
\text { характеризує окремі поняття та явища; відтворює незначну частину навчального } \\
\text { матеріалу; відсутня мотивація до навчально-пізнавальної та самостійної діяльності; } \\
\text { байдуже та фрормально ставиться до пошуку способів розв'язання навчальних } \\
\text { завдань. }\end{array}$ \\
\hline $\begin{array}{c}\text { Середній } \\
(21-40)\end{array}$ & $\begin{array}{l}\text { Уміє використовувати основні засоби ХОС. Фрагментарно володіє знаннями з дис- } \\
\text { ципліни; розуміє та може пояснити окремі поняття та явища; розкриває незначну } \\
\text { частину навчального матеріалу; має слабку мотивацію до навчальної та самостійної } \\
\text { діяльності; у мисленні окреслюється перехід від репродуктивних до пошукових фрорм. }\end{array}$ \\
\hline $\begin{array}{c}\text { достатній } \\
\text { (41-60) }\end{array}$ & $\begin{array}{l}\text { Уміє використовувати більшу частину засобів ХОс. Набув основних знань, умінь } \\
\text { і навичок із дисципліни; розуміє та може пояснити поняття та явища; наводить } \\
\text { власні приклади; розкриває значну частину навчального матеріалу; мотивований до } \\
\text { навчальної та самостійної діяльності. }\end{array}$ \\
\hline $\begin{array}{l}\text { Високий } \\
\text { (61-80) }\end{array}$ & $\begin{array}{l}\text { Уміє використовувати весь фрункціонал ХОс. Має ґрунтовні теоретичні знання та прак- } \\
\text { тичні вміння з дисципліни; вільно відповідає на запитання; аргументовано висловлює } \\
\text { власні думки; реалізує самостійну навчальну діяльність; проявляє творчу самостійну } \\
\text { активність і креативність при виконанні завдань. }\end{array}$ \\
\hline
\end{tabular}

дотримання показника, 3 - достатній рівень дотримання показника, 4 - високий рівень дотримання показника (показник дотримується повністю).

Підсумкова оцінка критерію сорормованості ППК окремого студента визначається як сума оцінок за кожним із показників певного критерію.

Сумарна оцінка за всіма критеріями, яка вказує на рівень сформованості вищезгаданої компетентності в майбутнього вчителя інформатики в ХОС у навчанні БД, обраховується за такою фрормулою:

$$
S_{n}=\sum_{i=1}^{m} \sum_{j=0}^{p} k_{i j} \text {, }
$$

де $S_{n}$ - сумарна оцінка показників зазначених критеріїв n-го майбутнього вчителя інформатики; $i=1,2, \ldots m$ - кількість критеріїв; $j=1,2, \ldots$ $p$ - кількість показників певного критерію; $k_{i j}$ оцінка ј-го показника і-го критерію.

Для визначення рівнів сфрормованості ППК майбутнього вчителя інфрорматики у навчанні БД у ХОС представимо підходи вітчизняних науковців щодо виокремлення рівнів сорормованості професійних компетентностей майбутніх учителів.

М.В. Попель [7] для кожної складової системи професійних компетентностей виокремлює чотири рівні: високий, достатній, середній, низький. Для кожного з них визначає показники сформованості.

М.В. Рафральска [8] виділяє три рівні сорормованості професійно-інформатичних компетентностей учителя: базовий (елементарний), середній (функціональний) та просунутий (системний). Для кожного рівня визначає певні критерії.

Я.Б. Сікора [9] пропонує чотирирівневу структуру професійної компетентності майбутніх учителів інфрорматики: адаптивний (низький), алгоритмічний (середній), частково-пошуковий (достатній), творчий (високий) рівні.
Представимо рівні сфрормованості ППК майбутнього вчителя інорорматики щодо використання ХOC у навчанні БД та показників для кожного з них у вигляді таблиці (табл. 2).

Отже, для визначення рівня сфрормованості ППК майбутнього вчителя інфрорматики щодо використання ХОС у навчанні БД із було визначено критерії, показники та рівні, за якими можна встановити, наскільки оволоділи студенти теоретичними знаннями концепції БД, практичними вміннями і навичками проектування, створення й адміністрування БД у сучасних СКБД та вміннями використовувати ХОС.

Висновки. Вивчення особливостей професійної підготовки майбутніх учителів інформатики у працях провідних учених дозволило виокремити різноманітні аспекти цієї проблеми у науковій літературі: методичну підготовку, кредитно-модульну систему навчання, організаційно-педагогічні умови формування професійної компетентності студентів, індивідуальний та диореренційований підходи, фрормування інфрормаційної та технологічної культури майбутнього вчителя тощо.

Здійснене дослідження дає можливість оцінити рівень сорормованості ППК майбутніх учителів інорорматики щодо використання ХОС у навчанні баз даних відповідно до визначених критеріїв (мотиваційний, організаційний, діяльнісний когнітивний, критерій навчальної взаємодії), їхніх показників та рівнів (низький, середній, достатній, високий).

\section{БІБЛІОГРАФІЧНИЙ СПИСОК:}

1. Вакалюк Т.А. Підготовка майбутніх учителів інформатики до розвитку логічного мислення старшокласників: теоретико-методологічний аспект : монографрія. Житомир : Вид-во ЖДУ ім. І. Франка, 2013. $236 \mathrm{c}$. 
2. Гирка І.В. Організаційно-педагогічні умови формування професійної компетентності майбутніх учителів інформатики в процесі фрахової підготовки. Обрії. 2015. № 1. С. 64-67.

3. Жалдак М.И. Система подготовки учителя к использованию информационной технологии в учебном процессе : автореф. дисс. ... докт. пед. наук : 13.00.02 / НИИ содержания и методов обучения АПН СССР. Москва, 1989. 48 с.

4. Коротун О.В. Оцінювання рівня сорормованості професійно-практичної компетентності майбутніх учителів інформатики у навчанні баз даних в умовах ХОНС. Зб. мат. звітної наукової конференції ІІТЗН НАПН України (м. Київ, 2017). URL: http://lib.iitta.gov.ua.

5. Коротун О.В. Педагогічний експеримент 3 проектування хмаро орієнтованого середовища у навчанні баз даних майбутніх учителів інформатики. Проблеми та інновації в природничо-математичній, технологічній і професійній освіті : зб. матеріалів Міжнар. наук.-практ. онлайн-інтернет конфр. Кропивницький, 2018. С. 69-70.

6. Морзе Н.В. Система методичної підготовки майбутніх вчителів інфрорматики в педаго- гічних університетах : авторедр. дис. ... докт. пед. наук : 13.00.02 / НПУ імені М.П. Драгоманова. Київ, 2003. 43 c.

7. Попель М.В. Хмарний сервіс Sagemathcloud як засіб фрормування профресійних компетентностей вчителя математики : дис. ... канд. пед. наук : 13.00.10 / Академія пед. наук України ; Ін-т інорормаційних технологій та засобів навчання. Київ, 2017. 311 c.

8. Рафральська М.В. Формування інформатичних компетентностей майбутніх вчителів інорорматики у процесі навчання методів обчислень: дис. ... канд. пед. наук : 13.00.02 / НПУ імені М.П. Драгоманова. Київ, 2010. 308 с.

9. Сікора Я. Б. Формування професійної компетентності майбутнього вчителя інфрорматики засобами моделювання : автореф. дис. ... канд. пед. наук : 13.00.04 / Житомир. держ. ун-т ім. І. Франка. Житомир, 2010. 22 с.

10.Спірін О.М. Теоретичні та методичні засади професійної підготовки майбутніх учителів інформатики за кредитно-модульною системою : монографрія / за наук. ред. М.І. Жалдака. Житомир : Вид-во ЖДУ ім. І. Франка, 2007. 300 с. 